\title{
The association between farm management strategies and irrigators' farm profits over time in the Murray-Darling Basin
}

\author{
A. Zuo ${ }^{1}$, S. Wheeler ${ }^{1}$, H. Bjornlund ${ }^{1,2}$ \& M. Shanahan ${ }^{1}$ \\ ${ }^{I}$ Centre for Regulation and Market Analysis, School of Commerce, \\ University of South Australia, Australia \\ ${ }^{2}$ Economics Department, University of Lethbridge, Canada
}

\begin{abstract}
This paper uses historical irrigator survey data from seven years between 199899 and 2010-11 to compare the net farm operating surplus amongst farmers who undertake various farm management strategies. There is evidence that the use of more intensive farm management strategies in the past five years is associated with higher levels of net farm operating surplus. In particular, farmers who have bought water entitlements in the past five years is associated with higher net farm operating surplus, while those that reduced their irrigated area were associated with a reduction in net farm operating surplus. However, the relationship between participating in the water market and net farm surpluses seems to be falling over time, potentially because of the continuing maturation and adoption of water markets by irrigators over time.
\end{abstract}

Keywords: water trading strategies, Murray-Darling Basin, farm profitability, irrigators.

\section{Introduction}

Most farmers have two common aspirations: to remain a farmer and to earn an acceptable standard of living. Farmers' perceptions of an acceptable standard of living change over time, and are dependent upon a range of other influences such as their age, family situation, alternative earning potential and region. Farm profitability, as it is one of the most important measurements of farmers' standard of living, has concerned policy makers for decades. 
Due to drought, from 2002-03 to 2009-10 the River Murray endured record low flows and irrigators in the Murray-Darling Basin (MDB) in Australia faced considerable stress in dealing with reduced water allocations, higher temperatures, reduced rainfall and falling commodity prices [1]. The drought was broken in 2010 with flooding across the MDB. The reduction in water allocations during the drought, and increased environmental stress in the past decade has led a large number of farmers to exit irrigation, although overall there has not been a concomitant reduction in production from irrigation. The changing structure of the irrigation farm sector does, however, have long-term consequences for productivity, efficiency and well-being of rural communities. Any structural change in response to water scarcity in the farm sector is likely to be subtle and gradual, initiated by various strategies irrigators employ. One of the major strategies to deal with water scarcity is trading in the water allocation and entitlement markets, while there are also a range of other strategies, such as adopting efficient irrigation infrastructure and management practices, changing crop mix, switching to alternative land uses.

The debates about the impact of government policy, the response of farmers and the role of the market are highly politicised across the southern MDB. The efficiency of water markets has been well publicised, as has their ability to provide farmers with an opportunity to supplement farm income through trading in allocation water. In general, markets allow farmers to achieve greater allocation efficiency and provide incentives to enhance technical efficiency. Allocative efficiency here refers to allocating water to where it generates the most value, while technical efficiency refers to the improvements in technology which improve the efficient use of water. A key question that has remained unanswered, however, is whether participation in water markets makes irrigation farms more viable. If water is moving to higher valued uses, is it moving to more profitable farms? Has the relationship between profit and water market participation changed over time? A better understanding of these relationships will allow the government to make well-informed and coherent water market related policy decisions within the southern MDB. Another important relationship this paper seeks to uncover is whether strategies undertaken by farmers involving their irrigation area, farm land and infrastructure are associated with net farm income.

\section{Water markets in Australia}

The southern interconnected MDB is comprised of irrigation districts located in New South Wales (NSW), Victoria and South Australia (SA). Historically farmers in these districts have received an allocation of water, regulated by government, and determined by factors including history of use, environmental conditions, and quantities stored upstream [2]. Unlike other areas in Australia, the southern MDB is hydrologically linked which allows water trade to occur. Change has occurred rapidly in recent years. While 1998-99 was the first year that irrigators within Australia's largest irrigation district, the Goulburn Murray Irrigation District (GMID) did not receive full water allocations in the first 
months of the water season, 2002-03 was the first year they did not receive their full water allocations by the end of the season. In 2008-09 all irrigators in the MDB had their allocations reduced, with Victorian irrigators in the Goulburn and Murray systems only receiving one-third of their water entitlements by the season's end and SA irrigators received less than one-fifth. Table 1 illustrates the historical profile of seasonal end water allocations in four regions across the southern MDB.

Table 1: $\quad$ Final water allocations (\%) in the Southern Murray-Darling Basin.

\begin{tabular}{|l|c|c|c|c|c|c|c|c|c|}
\hline & \multicolumn{4}{|c|}{ High reliability entitlements } & \multicolumn{3}{c|}{ Lower reliability entitlements } \\
\cline { 2 - 11 } & $\begin{array}{c}\text { Vic } \\
\text { Goulb } \\
\text { Yrn }\end{array}$ & $\begin{array}{c}\text { Vic } \\
\text { Yurray }\end{array}$ & $\begin{array}{c}\text { NSW } \\
\text { Murray }\end{array}$ & $\begin{array}{c}\text { NSW } \\
\text { Murrum } \\
\text { bidgee }\end{array}$ & $\begin{array}{c}\text { SA } \\
\text { Murray }\end{array}$ & $\begin{array}{c}\text { Vic } \\
\text { Goulburn } \\
\text { (low) }\end{array}$ & $\begin{array}{c}\text { Vic } \\
\text { Murray } \\
\text { (low) }\end{array}$ & $\begin{array}{c}\text { NSW } \\
\text { Murray } \\
\text { (general) }\end{array}$ & $\begin{array}{c}\text { NSW } \\
\text { Murrum } \\
\text { bidgee } \\
\text { (general) }\end{array}$ \\
\hline $1998-99$ & 100 & 100 & 100 & 100 & 100 & 0 & 100 & 93 & 85 \\
\hline $1999-00$ & 100 & 100 & 100 & 100 & 100 & 0 & 90 & 35 & 78 \\
\hline $2000-01$ & 100 & 100 & 100 & 100 & 100 & 0 & 100 & 95 & 90 \\
\hline $2001-02$ & 100 & 100 & 100 & 100 & 100 & 0 & 100 & 105 & 72 \\
\hline $2002-03$ & 57 & 100 & 100 & 100 & 100 & 0 & 29 & 10 & 38 \\
\hline $2003-04$ & 100 & 100 & 100 & 95 & 95 & 0 & 0 & 55 & 41 \\
\hline $2004-05$ & 100 & 100 & 97 & 95 & 95 & 0 & 0 & 49 & 40 \\
\hline $2005-06$ & 100 & 100 & 97 & 95 & 100 & 0 & 0 & 63 & 54 \\
\hline $2006-07$ & 29 & 95 & 69 & 90 & 60 & 0 & 0 & 0 & 10 \\
\hline $2007-08$ & 57 & 43 & 50 & 90 & 32 & 0 & 0 & 0 & 13 \\
\hline $2008-09$ & 33 & 35 & 95 & 95 & 18 & 0 & 0 & 9 & 21 \\
\hline $2009-10$ & 71 & 100 & 97 & 95 & 62 & 0 & 0 & 27 & 27 \\
\hline $2010-11$ & 100 & 100 & 100 & 100 & 67 & 0 & 0 & 100 & 100 \\
\hline
\end{tabular}

Water markets were initiated in Australia in the southern MDB in the early 1980 s, and since then, trade in water allocations (water allocated seasonally based on water entitlement and availability) and water entitlements (the long term right to receive seasonal water allocations) have increased considerably. Allocation trade was adopted far earlier than entitlement trade. As illustrated in Figure 1, there was a significant increase in the volume of trade following the establishment of the Interim Cap in the mid 1990s, which capped the volume of surface water extractions. Over the decade trade volumes have increased in response to climate and water supply variability and the implementation of water market reforms. It also reflects irrigators' growing acceptance, adoption and learning of the water market [3]. Allocation trade volumes have been high since the 1990s, but it has only been since 2007-08 that there has been considerable growth in entitlement trade, driven primarily by Federal government purchasing of water entitlements and the severe drought [2]. 


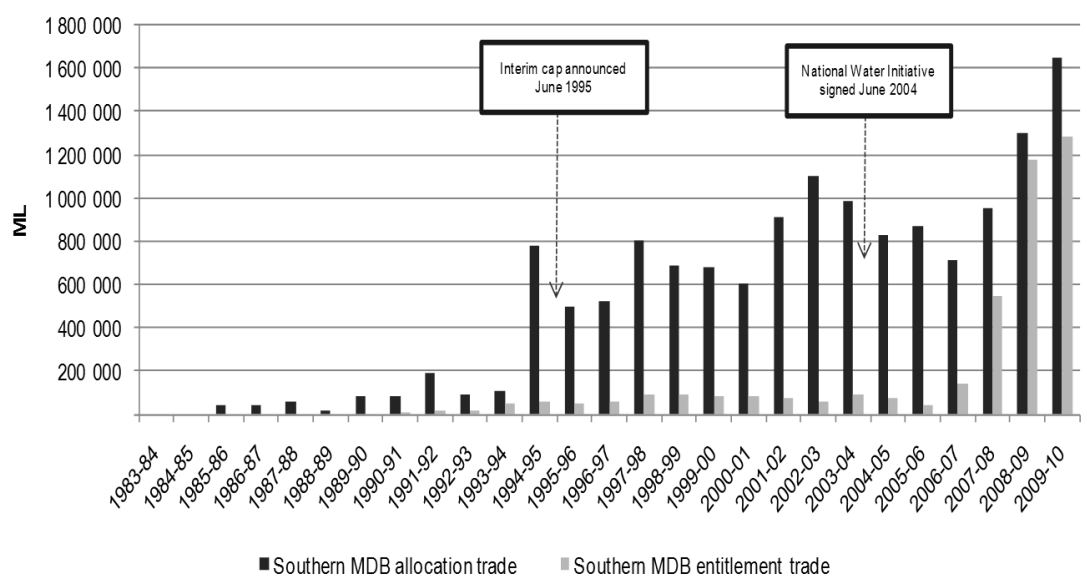

Figure 1: Volume of allocation and entitlement trades in the sMDB 1983-84 to 2009-10. Only includes trades from regulated water from: Lower Darling, NSW Murray, Murrumbidgee, South Australian Murray, Victorian Murray, Goulburn and Campaspe/Loddon [2].

The development of water markets in Australia is considered, in general, to have allowed the movement of water from lower valued, inefficient uses (such as rice and cotton farming) to higher valued uses (horticulture). The ability to trade water provides flexibility for irrigators in water use, production and farm management strategies. Assuming farmers are profit maximisers (or loss minimisers) one could expect that participation in water markets should contribute to higher farm profits. For sellers, water sales should provide additional income in excess of any reduction in income associated with lower irrigated production. For buyers, water purchases should enable the generation of additional irrigated production income above the total cost of the additional water. Although trade in either entitlement or allocation markets should contribute to higher farm profits, there may be a lag between such trading and the long-term impact on profits, particularly for water entitlements [4]. As Qureshi et al. [5] argues, trading in water markets is likely to increase and improve economic efficiency because market prices make the opportunity cost of water explicit; they provide incentives to adopt water-saving technologies and reduce inefficient uses of water. NWC [6] suggested that water trading in the southern MDB increased Australia's gross domestic product by $\$ 220$ million in 2008-09, and Qureshi et al. [5] found that a reduction in water market barriers in the sMDB would increase annual net returns significantly.

Overall, irrigation districts in NSW have been a net exporter of water (especially the Murrumbidgee), and the Goulburn and SA Murray net importers over the past decade. Water has moved from predominantly annual crops (such as rice/cotton and mixed farming) to dairy and horticulture crops. Results from irrigation farm level data analysis in Hughes [7] and Bell et al. [4] confirm prior 
expectations that demand for water in perennial horticulture activities and vegetable production is generally more inelastic relative to broadacre activities such and dairy.

\section{Other farm management strategies}

To manage the impact of climate variability, output prices and input costs on net returns, farmers routinely adopt mitigation strategies involving various adjustments in enterprise mix, selling and buying land, hedging strategies, production insurance, earning off-farm income and adopting new management practices and production technologies. Irrigators may also implement other strategies to reduce their exposure to risk, such as adopting more efficient irrigation infrastructure, reducing production of high water use crops and switching to alternative land uses. Increasing output (through buying additional water entitlements or land) is a strategy irrigators may adopt to capture benefits from economies of scale. Decreasing output (selling water entitlements or land) is an option for decreasing debt (and interest payments) and perhaps reducing inefficient use of resources.

In the context of this paper, we focus on strategies involving irrigation land and farm land. Zuo et al. [8] categorise the strategies into 'intensive' and 'defensive'. Intensive strategies include purchasing land, increasing irrigation area, and having adopted irrigation efficiency improvements. Generally in agriculture, intensive strategies in competitive markets tend to result in more efficient farms that adapt to the changing external environment and, therefore, are able to remain in farming.

Defensive strategies consist of selling land and reducing irrigation area. Defensive strategies may result in inefficient businesses, liquidation or even exit [9]. However, this may not be the case for irrigators. Irrigators deploying defensive strategies generally try to find ways of staying on the farm and within the community until retirement. There is a broad literature in agricultural economics on the best strategies for farmers to employ under the threat of drought, albeit most of this work is based on the experience of dryland farmers. Defensive strategies can be a viable drought response to minimise costs and debt, and hence lead to more profits for farmers undertaking them than farmers who do not.

This paper takes a very broad overview and provides a comparison from historical survey data on how the farm management strategies including water trading strategy choice are associated with net farm operating surplus.

One of the factors that determine whether a farm will survive is the ability of the farm operator to generate profit. Much of the literature on farm profitability in Australia has been based on farm simulation models; bio-economic modelling (e.g. [10]); and farm censuses and surveys [4, 7, 11]. The most used estimate of farm profitability is 'whole-farm net income'. A positive value for net farm income is critical to the survival of a farm. Most farmers must balance equity growth with the need to meet short-term cash commitments. 


\section{Data and methodology}

This study presents data from five historical irrigator surveys in the southern MDB. The survey data (1998-99, 2003-2006, 2008-09 and 2010-11) are described in detail in Wheeler et al. [12]. Two surveys were conducted in New South Wales and GMID, Victoria respectively, in the 1998-99 season. Three annual surveys in the GMID were collected from the 2003-04 to 2005-06 seasons. There was one survey for GMID and the Riverland area in SA in 200809 and the last survey was for GMID, SA and NSW in 2010-11. The total sample size used was 3,253 records over time.

We grouped farmers undertaking the same strategy under each theme together and calculate their mean farm operational surplus. We then conducted a multivariate test on the means to test whether the mean surpluses are the same across different groups of farmers. There are five strategies overall we investigated, namely: water entitlements, water allocations, farmland, irrigated areas and irrigation infrastructure improvements. Under each theme, farmers choose to undertake different options. The first column in Table 2 provides the description of the different groups. For example, for water allocations, farmers have four options, including neither buying nor selling water allocations, only buying, only selling, and both buying and selling. Since not all surveys were designed for the research question of this paper, we do not have a full range of choices available under each strategy. For example, the 1998-99 surveys had no questions on the farm area changes made in the past five years.

It is important to bear in mind that our classification of groups of farmers under different strategies is only done on an indication basis of practice only (e.g. did farmers do the strategy at all versus otherwise). It does not take into consideration the wide difference in implementation of actual strategies (for example, selling $1 \mathrm{ML}$ of water versus selling $1000 \mathrm{ML}$ of water). Such analysis is left for future research.

\section{Results and discussion}

Table 2 shows the mean net farm operational surplus of irrigators who undertook past water, land and infrastructure management strategies in our surveys from 1997/98 to 2009/10 (note: net farm operational surplus was collected from the year previous to the year in which the survey was conducted). The shaded numbers in the table illustrate the highest net operating surplus of each management strategy choice by category. In Table 3, we present the net farm operational surplus for the annual and permanent crop industries for the 2008-09 and 2010-11 seasons.

\subsection{Water trading strategies and net farm operational surplus}

For strategies regarding water entitlements, farmers who purchased water entitlements in the past five years have the highest mean surplus for all the 


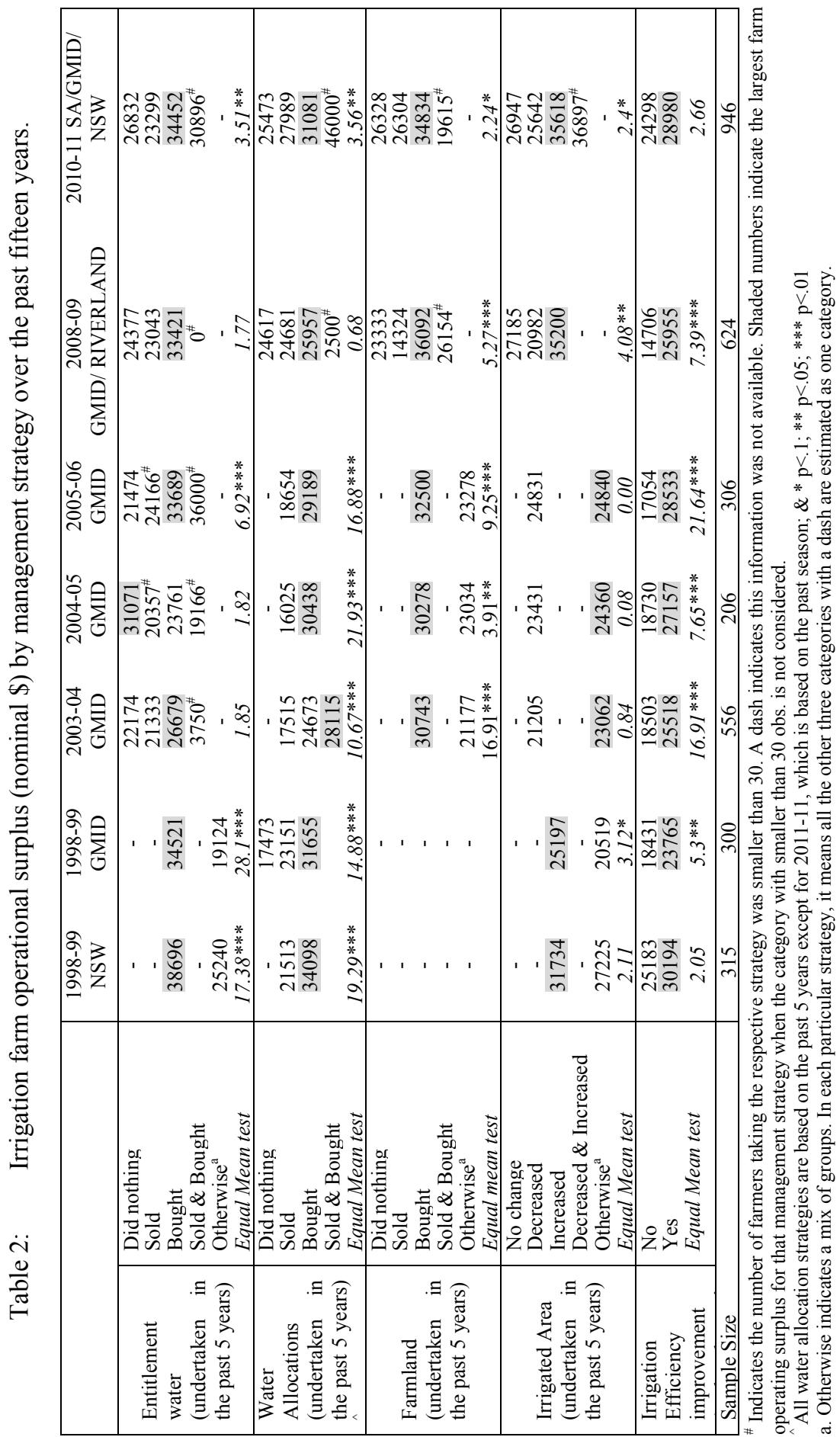


Table 3: Irrigation farm operational surplus (nominal \$) by management strategy and industry for 2008-09 and 2010-11.

\begin{tabular}{|c|c|c|c|c|c|}
\hline & \multicolumn{2}{|c|}{$2008-09^{1}$} & \multicolumn{2}{|c|}{$2010-11$} \\
\hline & & Annual & Permane & Annual & Permane \\
\hline \multirow{5}{*}{$\begin{array}{l}\text { Water } \\
\text { Entitlements }\end{array}$} & Did nothing & $23704^{\#}$ & 23256 & 26194 & 27752 \\
\hline & Sold & $30000^{\#}$ & $28000^{\#}$ & 20952 & 23000 \\
\hline & Bought & $40000^{\#}$ & $32500^{\#}$ & 35532 & 33662 \\
\hline & Sold and Bought & - & $0^{\#}$ & 35588 & $12222^{\#}$ \\
\hline & Equal Mean test & 0.46 & 1.04 & $2.57 *$ & $2.34^{*}$ \\
\hline \multirow{5}{*}{$\begin{array}{l}\text { Water } \\
\text { Allocations }\end{array}$} & Did nothing & $2500^{\#}$ & 14828 & 25541 & 24872 \\
\hline & Sold & $23750^{\#}$ & $12857^{\#}$ & 25319 & 34848 \\
\hline & Bought & $27647^{\#}$ & 26059 & 31594 & 29403 \\
\hline & Sold and Bought & $53333^{\#}$ & $31364^{\#}$ & $40000^{\#}$ & $55000^{\#}$ \\
\hline & Equal Mean test & 1.64 & $2.87 * *$ & 0.99 & 1.38 \\
\hline \multirow[t]{5}{*}{ Farmland } & Did nothing & $20833^{\#}$ & 22286 & 26699 & 25981 \\
\hline & Sold & $50000^{\#}$ & $16429^{\#}$ & $22174^{\#}$ & $24444^{\#}$ \\
\hline & Bought & $40000^{\#}$ & $35862^{\#}$ & 30694 & 42000 \\
\hline & Sold and Bought & - & $100000^{\#}$ & $25000^{\#}$ & $14000^{\#}$ \\
\hline & Equal Mean test & 1.35 & $6.54 * * *$ & 0.44 & $2.37 *$ \\
\hline \multirow{5}{*}{$\begin{array}{l}\text { Irrigated } \\
\text { Area }\end{array}$} & Unchanged & $23684^{\#}$ & 24576 & 27315 & 26395 \\
\hline & Decreased & $27000^{\#}$ & 21667 & 23510 & 24390 \\
\hline & Increased & $36667^{\#}$ & $29412^{\#}$ & 33636 & $43200^{\#}$ \\
\hline & Decreased and & - & - & $42353^{\#}$ & $37500^{\#}$ \\
\hline & Equal Mean test & 0.22 & 0.58 & $2.19^{*}$ & $2.28^{*}$ \\
\hline \multirow{3}{*}{$\begin{array}{l}\text { Efficiency } \\
\text { improvement }\end{array}$} & No & $2500^{\#}$ & $19286^{\#}$ & 23100 & 26780 \\
\hline & Yes & 29286 & 24389 & 29045 & 27789 \\
\hline & Equal Mean test & 2.70 & 0.71 & 2.04 & 0.71 \\
\hline
\end{tabular}

\# Indicates the number of farmers taking the respective strategy was smaller than 30. A dash indicates there is no farmer undertaking this strategy. Shaded numbers indicate the strategy with the highest net farm operating surplus within the management strategy

${ }^{1}$ This included GMID and Riverland, and 2010-11 included NSW, SA and VIC. A All the strategies are based on the past five years except that the 2010-11 water allocation strategies were based on the past season.

$* \mathrm{p}<.1 ; * * \mathrm{p}<.05 ; * * * \mathrm{p}<.01$.

surveys except for the 2004-05 survey results. For the industry level data, the purchasing water entitlement strategy also appeared to be associated with higher surplus. Generally farmers who sold water entitlements in the past five years have the lowest mean surplus, although in some years the number of farmers 
selling water was quite small. The mean comparison test indicates that for four out of the seven surveys, farmers' surpluses differ significantly across the strategy groups involving water entitlements.

Analysing our data by who trades (or who does not trade) water allocations has a similar story to water entitlements. Farmers buying water allocations are generally associated with higher net operating surpluses. The difference in surplus among the strategy groups of water allocations appeared relatively larger in the early years compared with the most recent years. Particularly in the 200809 survey, the difference in surplus among the groups is not statistically significant and the difference in the 2010-11 survey is only statistically significant at the 5 per cent level. At the industry level, there is only a statistically significant difference for the permanent crop industry in the 2008-09 survey.

\subsection{Other strategies and net farm operational surplus}

Farmers who bought land in the past five years had the highest mean net farm operating surplus across the different groups. Across the strategies, it seems that farmers who buy land, as well as those who buy water entitlements, have the highest net farm operating surplus. The difference among the different strategy groups involving farmland is also statistically significant at the 10 per cent level at least. At the industry level, the same result holds for those irrigating permanent crops while for those irrigating annual crops the difference in surpluses among the strategy groups is not statistically significant, possibly due to the small number of observations in this industry.

Regarding irrigation area strategies, the difference in surplus is only statistically significant in three surveys, 1998-99 GMID, 2008-09 and 2010-11. In these surveys, increasing irrigation area in the past five years is associated with higher mean net farm operating surplus than other strategies. The same result was found at the industry level, although the number of farms in this category is relatively small and results should be treated with caution.

Farmers who made irrigation efficiency improvements in the past generally have higher mean net farm operating surpluses than those who did not, with statistical significance found in five out of the seven surveys. Potentially due to the smaller number of observations, no statistical difference was found at the industry level.

The key conclusions from the above analysis suggests that in general, farmers who undertook intensive strategies in the past such as buying water, increasing irrigation area, buying farm land and undertaking irrigation efficiency improvements, were more likely to have higher net farm operating surpluses than farmers associated with more contractive or less intensive strategies. There was more statistical significance found in the results for those buying water allocations than those buying water entitlements, and there seemed to be greater differences in farm net income in the earlier years between water trading strategies than later years. 


\section{Conclusions}

There is evidence that the implementation of more intensive farm management strategies in the past is associated with higher levels of net farm operating surplus. In particular, farmers who have bought water entitlements and allocations in the past five years is associated with higher net farm operating surplus, while those that reduced their irrigated area were associated with a reduction in net farm operating surplus. However, the relationship between participating in the water market and positive net farm surpluses seems to be falling over time. There are several possible reasons for this. One is that perhaps those who entered the markets 'early' (pre 2000) have either re-established the balance between water trading and farm profitably, or left the industry. A higher proportion of farmers who are now (2009-2011) involved with water trading are more likely to view the market as but one of several strategies to remain on their farms. The continuing maturation and adoption of water markets by irrigators, especially the market for water allocations, signals that the majority of farmers now use the market. Some use it because they are more productive and water efficient, while others use it as a retirement strategy or to buy water in desperate times. Further analysis is needed to fully understand the relationship between farm profitability and farm and farmer characteristics, institutional factors and management strategies. Preferably, such research would involve panel data analysis over time, to capture effects of selling water entitlements on future years.

\section{References}

[1] Commonwealth Scientific and Industrial Research Organisation (CSIRO), Water Availability in the Murray-Darling Basin Report. Report from CSIRO to the Australian Government by CSIRO Murray-Darling Basin Sustainable Yields Project, Canberra, 2008.

[2] National Water Commission (NWC), Australian Water Markets: trends and drivers 2007-08 to 2009-10, Commonwealth of Australia, Canberra, 2011.

[3] Wheeler, S., Bjornlund, H., Zuo, A. and Shanahan, M., The Changing Characteristics of Traders in the Goulburn Murray Irrigation District, Australia, Agr. Water Manage., 96, pp. 121-131, 2010.

[4] Bell, R., Gali, J., Gretton, P. and Redmond, I., The responsiveness of Australian farm performance to changes in irrigation water use and trade, paper presented at the 51st Annual Conference of the Australian Agricultural and Resource Economics Society, 14-16 February, 2007.

[5] Qureshi, M.E., Shi, T., Qureshi, S. and Proctor, W., Removing barriers to facilitate efficient water markets in the Murray-Darling Basin of Australia, Agr. Water Manage., 96(11), pp. 1641-1651, 2009.

[6] National Water Commission (NWC), The impacts of water trading in the southern Murray-Darling Basin: An economic, social and environmental assessment, Commonwealth of Australia, Canberra, 2010. 
[7] Hughes, N., Estimating irrigation farm production functions with ABARES survey data, paper presented at AARES, 9-11 February 2011, Melbourne, Victoria, 2011.

[8] Zuo, A., Wheeler, S., and Bjornlund, H., Analysing the drivers of irrigator drought strategies in the Southern Murray-Darling Basin, in Brebbia $C$ and Popov V (eds) Water Resources Management VI, WIT press, UK, pp. 597607, 2011.

[9] David, F.R., Strategic Management Concepts and Cases, $12^{\text {th }}$ ed., Prentice Hall, Upper-Saddle River, NJ, 2009.

[10] Kingwell, R., Managing complexity in modern farming, Aust. J. Agri. Resour. Econ., 55, pp. 12-34, 2011.

[11] Barr, N., 'Self-reliance' in Victorian agriculture. Structural capacity, restructuring progress and future investment in evidence-based policy. Draft working paper, $<$ http://sites.google.com/site/ruralsociallandscapes /publications/adjustment-policy> (accessed 10.7.11).

[12] Wheeler, S., Bjornlund, H., Zuo, A. and Edwards, J., Handing down the farm? The increasing uncertainty of irrigated farm succession in Australia, J. Rural Stud., 28(3), pp. 266-275, 2012. 